\title{
Maxillary osteonecrosis associated to antiangiogenic drugs
}

\author{
Cesar Salort-Llorca ${ }^{1}$, Mari-Paz Mínguez-Serra ${ }^{2}$, Francisco-Javier Silvestre-Donat ${ }^{2,3}$ \\ ${ }^{1}$ Pharmacist. Specialist in Hospital Pharmacy \\ ${ }^{2}$ Stomatology Unit. Doctor Peset University Hospital. Valencia (Spain) \\ ${ }^{3}$ Department of Stomatology. Valencia University Medical and Dental School. Valencia (Spain)
}

Correspondence:

Unidad de Estomatología

Hospital Dr. Peset. Consultas Externas

C/ Juan de Garay s/n

46017 - Valencia (Spain)

francisco.silvestre@uv.es

Salort-Llorca C, Mínguez-Serra MP, Silvestre-Donat FJ. Maxillary osteonecrosis associated to antiangiogenic drugs. Med Oral Patol Oral Cir Bucal. 2011 Mar 1;16 (2):e137-8.

http://www.medicinaoral.com/medoralfree01/v16i2/medoralv16i2p137.pdf

Received: 03/11/2009

Accepted: 21/02/2010

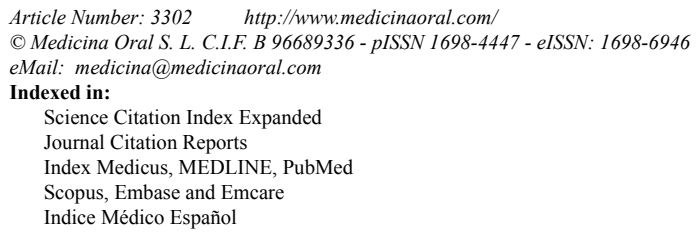

\section{To the Editor}

Maxillary osteonecrosis (MON) associated to bisphosphonate (BP) use is a slow-evolving (over 6 weeks) form of chronic osteomyelitis characterized by the exposure of mandibular or maxillary bone seen in patients administered present or past BP therapy, and who have not been subjected to maxillofacial radiotherapy and show no evidence of metastatic disease (1).

Different studies have identified a series of risk factors for BP-induced MON, including the use of nitrogenated BPs, the duration of treatment, concomitant corticoid use, or dental surgical procedures. A number of hypotheses have been proposed in an attempt to explain BP-induced MON. At tissue level, some authors consider MON to be due to diminished bone turnover, with the inhibition of bone resorption, while at cellular level other investigators postulate an inhibition of osteoclast recruitment and activity at bone surface level - favoring apoptosis. Interaction would take place with a receptor or intracellular enzyme within the osteoclasts, resulting in the inhibition of ATP-dependent enzymes. Likewise, and although still subject to controversy, an antiangiogenic effect is observed, acting mainly upon the soft tissues - with no evidence to suggest that this effect occurs during the bone remodeling process (2).

Different antineoplastic drugs are presently used in which the mechanism of action involves the suppression of some stage of angiogenesis. Tumor angiogenesis is characterized by the proliferation of blood vessels within the neoplasm, transporting oxygen and nutrients to the tumor cells and facilitating tumor growth.

If the inhibition of angiogenesis is one of the factors related to the production of MON, then antineoplastic drugs that act via an antiangiogenic mechanism could contribute to trigger or facilitate MON in patients treated with BPs.

Bevacizumab (Avastin $\left.{ }^{\circledR}\right)$ is a monoclonal antibody that binds to vascular endothelial growth factor (VEGF) -a key element in vasculogenesis and angiogenesisthereby preventing VEGF from binding to its receptors. Such neutralization of the biological activity of VEGF induces the regression of tumor vascularization, normalizing tumor residual vascularization, and inhibiting tumor neovascularization. Tumor growth is inhibited as a result.

Different authorsd have related the use of bevacizumab to an increased risk of MON in patients treated with BPs (3-5), with prevalences of up to $16 \%$ in patients administered bevacizumab and BPs versus only $1 \%$ in patients treated only with BPs (3). It was postulated that bevacizumab and other antiangiogenic drugs could exert an inducing effect favoring the development of 
Table 1. Description of the cases of maxillary osteonecrosis induced by bevacizumab.

\begin{tabular}{|c|c|c|c|c|c|c|c|c|c|c|}
\hline Sex & Age & Diagnosis & Dosage & $\begin{array}{c}\text { No. } \\
\text { Cycles }\end{array}$ & $\begin{array}{c}\text { Time to } \\
\text { appearance }\end{array}$ & Size & Treatment & Resolution & Infection & $\begin{array}{c}\text { Dental } \\
\text { surgery }\end{array}$ \\
\hline $\mathrm{F}$ & 51 & Breast cancer & $\begin{array}{c}15 \mathrm{mg} / \mathrm{kg} / 21 \\
\text { days }\end{array}$ & 8 & 30 weeks & $1 \times 1 \mathrm{~mm}$ & $\begin{array}{c}\text { Curettage }+ \\
\text { CHX }\end{array}$ & YES & YES & YES \\
\hline$F$ & 33 & $\begin{array}{c}\text { Glioblastoma } \\
\text { multiforme }\end{array}$ & $\begin{array}{c}10 \mathrm{mg} / \mathrm{kg} / 14 \\
\text { days }\end{array}$ & 6 & 13 weeks & $1 \times 2 \mathrm{~cm}$ & None & YES & NO & NO \\
\hline$F$ & 63 & Breast cancer & NA & NA & 8 weeks & NA & Curettage & YES & YES & YES \\
\hline
\end{tabular}

NA - information not available; $\mathrm{CHX}$ - chlorhexidine; $\mathrm{F}=$ female.

MON. Posteriorly, it was seen that bevacizumab could lead to MON in patients that had not been treated with BPs. To date, three cases have been reported of MON in patients not administered BPs, attributable to treatment with bevacizumab $(6,7)$. These cases are summarized in (Table 1).

On the other hand, sunitinib $\left(\right.$ Sutent $\left.^{\circledR}\right)$ is an antineoplastic drug that inhibits multiple tyrosine kinase receptors implicated in tumor growth, neoangiogenesis and metastatic cancer progression. Among other receptors, this drug inhibits the range of VEGF receptors (VEGFR 1,2 and 3).

Likewise, sunitinib was initially suggested to be able to induce MON (8), and was posteriorly linked to MON in a clinical case (9). The latter corresponded to a 59year-old woman diagnosed with renal carcinoma that had metastasized to the lungs, and who received BP for 6 months. Posteriorly, after three months of treatment with sunitinib, she developed MON. Extension of sunitinib for another three months was decided, and the MON worsened considerably. On suspending the treatment, the osteonecrosis stabilized and improved. After 5 months without treatment, her lung metastases progressed, and sunitinib was reintroduced - MON reappearing as a result.

Other marketed drugs with antiangiogenic activity that have not been linked to date to the induction of MON include sorafenib, cetuximab and panitumumab. On the other hand, a range of new molecules that act upon some of the phases of angiogenesis are currently in the investigational stage.

It is necessary to identify all the risk factors that may influence the development of MON, with a view to preventing the disorder. Such factors must be taken into consideration before treatment (10), since to date there is no fully satisfactory management option for established MON.

\section{References}

References with links to Crossref - DOI

1. Bagan J, Scully C, Sabater V, Jimenez Y. Osteonecrosis of the jaws in patients treated with intravenous bisphosphonates (BRONJ): A concise update. Oral Oncol. 2009;45:551-4.

2. Allen MR, Burr DB. The pathogenesis of bisphosphonate-related osteonecrosis of the jaw: so many hypotheses, so few data. J Oral Maxillofac Surg. 2009;67:61-70.

3. Aragon-Ching JB, Dahut WL. Osteonecrosis of the jaw and the use of antiangiogenic agents: just an association? Oncologist. 2008;13:1314.

4. Aragon-Ching JB, Ning YM, Chen CC, Latham L, Guadagnini JP, Gulley JL, et al. Higher incidence of Osteonecrosis of the Jaw (ONJ) in patients with metastatic castration resistant prostate cancer treated with anti-angiogenic agents. Cancer Invest. 2009;27:221-6.

5. Christodoulou C, Pervena A, Klouvas G, Galani E, Falagas ME, Tsakalos G, et al. Combination of bisphosphonates and antiangiogenic factors induces osteonecrosis of the jaw more frequently than bisphosphonates alone. Oncology. 2009;76:209-11.

6. Estilo CL, Fornier M, Farooki A, Carlson D, Bohle G 3rd, Huryn JM. Osteonecrosis of the jaw related to bevacizumab. J Clin Oncol. 2008;26:4037-8.

7. Greuter S, Schmid F, Ruhstaller T, Thuerlimann B. Bevacizumabassociated osteonecrosis of the jaw. Ann Oncol. 2008;19:2091-2.

8. Ayllon J, Launay-Vacher V, Medioni J, Cros C, Spano JP, Oudard S. Osteonecrosis of the jaw under bisphosphonate and antiangiogenic therapies: cumulative toxicity profile? Ann Oncol. 2009;20:600-1.

9. Brunello A, Saia G, Bedogni A, Scaglione D, Basso U. Worsening of osteonecrosis of the jaw during treatment with sunitinib in a patient with metastatic renal cell carcinoma. Bone. 2009;44:173-5.

10. Bagán J, Blade J, Cozar JM, Constela M, García Sanz R, Gómez Veiga F, et al. Recommendations for the prevention, diagnosis, and treatment of osteonecrosis of the jaw (ONJ) in cancer patients treated with bisphosphonates. Med Oral Patol Oral Cir Bucal. 2007;12:E33640 . 